\title{
A Novel Silver Nanoparticles-based Sensing Probe for the Detection of Japanese Encephalitis Virus Antigen
}

(Penderia Baru yang Berasaskan Nano zarah Perak untuk Pengesanan Antigen Virus Ensefalitis Jepun)

\author{
Lih Shan Lim, Suk Fun Chin*,Suh Cem Pang, Magdline Sia Henry Sum \& David Perera
}

\begin{abstract}
A novel silver nanoparticles (Ag NPS)-based optical sensing probe has been developed for the detection of Japanese Encephalitis virus (JEV). Ag NPS were initially deposited onto amine functionalized glass slides. Subsequently, JEV antibodies were self-assembled onto surfaces of Ag NPs to form optical sensing probes. The detection of JEV antigen was observed via changes in light absorbance by Ag NPS upon occurrence of JEV antigen-antibody bindings. A highly sensitive and rapid optical sensing probe for JEV antigen with a detection limit of $12.8 \mathrm{ng} / \mathrm{mL}($ for $\mathrm{S} / \mathrm{N}$ ratio $=3)$ and an analysis assay time of $1 \mathrm{~h}$ had been demonstrated.
\end{abstract}

Keywords: Antibody; biosensor; Japanese Encephalitis Virus (JEV) antigen; optical sensing probe; silver nanoparticles $(A g N P S)$

\section{ABSTRAK}

Biopenderia optik baru yang berasaskan nano zarah perak (Ag NPS) telah dihasilkan untuk pengesanan antigen virus Ensefalitis Jepun (JEV). Ag NPS telah dimendapkan di atas slaid kaca yang difungsikan dengan amino. Seterusnya antibodi JEV dipegunkan pada permukaan Ag NPs untuk membentuk biopenderia optik. Pengesanan terhadap JEV antigen diperhatikan melalui perubahan penyerapan cahaya oleh Ag NPs apabila berlakunya pengikatan antara JEV antigen dan antibodi. Satu biopenderia optik yang sensitif bagi pengesanan JEV dengan had pengesanan (LOD) sebanyak 12.8 $n g / m L$ (ratio $S / N=3$ ) dan 1 jam masa analisis telah dihasilkan.

Kata kunci: Antibodi; antigen virus Ensefalitis Jepun (JEV); biopenderia; nano zarah perak (Ag NPS); perangsang optik

\section{INTRODUCTION}

Japanese encephalitis virus (JEV) is one of the leading causes of childhood encephalitis infection in Asia. It has a fatality rate of close to $30 \%$ (Solomon 1997) and neurological complications in $30 \%$ to $50 \%$ of those infected with JEV (Solomon et al. 1998). Globally, approximately three billion people are exposed and at risk of JEV infection (Oya \& Kurane 2007). Nearly 68,000 clinical cases of JEV infection are reported worldwide each year (Campbell et al. 2011). Rapid detection of JEV infection at an early stage would be important for early clinical intervention and prevention of a JEV outbreak.

Several conventional diagnostic methods have been developed for the detection of JEV infection, such as, enzyme-linked immunoglobulin assay (ELISA), plaque reduction neutralization test (PRNT) (Lee et al. 2014; Sirivichayakul et al. 2014) and reverse transcription polymerase chain reaction (RT-PCR) (Swami et al. 2008). Nonetheless, all of these diagnostic techniques have disadvantages such as high cost of consumables, expensive instrumentation and long analysis assay time (Chen et al. 2011). Most importantly, they are not suitable to be used at remote rural areas, where there are high frequencies of JEV infection (Kumar et al. 2012). During the past decade, various types of biosensors had been developed to replace conventional diagnostic methods. These biosensors offer advantages such as short analysis assay time, inexpensive instrumentation and easy operation (Labib et al.2011; Li et al. 2011; Tam et al. 2010; Tran et al. 2012). In 2011, Li et al. reported a novel magnetite bead-based electrochemical immunoassay technique for the diagnosis of JEV infection. Subsequent studies by Tran et al. (2012) demonstrated the use of an immunosensor for the detection of JEV antigen using an electrochemical immunosensing method.

Noble metal nanomaterials such as gold and silver are known to have extraordinary and size-dependent optical properties. These nanoparticles possess strong absorption properties in the visible region, often known as the localized surface plasmon resonance. Surface plasmon resonance happens when the incident photon frequencies are resonant with the collective oscillations of conduction electrons of the metal nanomaterials (Zhao et al. 2006). Among noble metal nanomaterials, silver nanoparticles (Ag NPs) have received considerable attention due to their attractive physico-chemical properties. Surface plasmon resonance and large effective scattering cross section of Ag NPs (Jensen et al. 2000) make them ideal candidates as nanoscale optical biosensors (Riboh et al. 2003). The surface plasmon energy and intensity of Ag NPs have been found to be sensitive to a number of factors, including 
particle conformation, type of buffer, particle size and shape (Chin et al. 2009; Szymanski et al. 2013). In addition, $\mathrm{Ag}$ NPs can be easily synthesized at cheaper cost when compared with gold nanoparticles.

In this paper, we report a novel optical sensing probe for the detection of JEV antigen, fabricated by depositing Ag NPs onto amine functionalized glass slides. To the best of our knowledge, this is the first study that reports on the use of an Ag NPs-based optical biosensor for the detection of JEV antigen.

\section{MATERIALS AND METHODS}

\section{REAGENT AND APPARATUS}

3-Aminopropyl triethoxysilane (APTES, $99 \%$ ), trisodium citrate $\left(\mathrm{Na}_{3} \mathrm{C}_{6} \mathrm{H}_{5} \mathrm{O}_{7}\right)$ and phosphate-buffered saline ( $\mathrm{PBS}, \mathrm{pH}$ 7) consisting of $10 \mathrm{mM}$ each of monosodium phosphate $\left(\mathrm{NaH}_{2} \mathrm{PO}_{4}\right)$ and disodium phosphate $\left(\mathrm{Na}_{2} \mathrm{HPO}_{4}\right)$ were obtained from Sigma-Aldrich. Absolute ethanol was purchased from $\mathrm{HmbG}$. Bovine serum albumin (BSA) and silver nitrate $\left(\mathrm{AgNO}_{3}\right)$ were purchased from Merck. Hydrogen peroxide $\left(\mathrm{H}_{2} \mathrm{O}_{2}, 30 \% \mathrm{v} / \mathrm{v}\right)$ and sulphuric acid $\left(\mathrm{H}_{2} \mathrm{SO}_{4}, 98 \% \mathrm{v} / \mathrm{v}\right)$ were purchased from J. T. Baker. Borosilicate glass slides $(22 \times 22 \mathrm{~mm}$, thickness: 0.1 - $1.0 \mathrm{~mm}$ ) were purchased from $\mathrm{GmbH}$. JEV E specific monoclonal antibody (Clone: ID MV12/1/C2-2/1) and JEV (Cardosa et al. 2002) were provided by the Institute of Health and Community Medicine, Universiti Malaysia Sarawak. All chemicals were used without further purification. Ultrapure water $\left(\sim 18.2 \mathrm{M} \Omega / \mathrm{cm}, 25^{\circ} \mathrm{C}\right)$ was used in all syntheses.

\section{CHARACTERIZATION}

The absorption spectra of Ag NPs-based sensing probes were measured with a UV/Vis Spectrophotometer (Shimadzu UV-160A). All measurements were made directly by placing the sensing probes perpendicular to the light beam of the spectrophotometer, within the wavelength range of $300-800 \mathrm{~nm}$. Fourier transformed infra-red (FTIR) spectra of samples were obtained from $\mathrm{KBr} / \mathrm{sample}$ pellets within the wavenumber range of $400-4000 \mathrm{~cm}^{-1}$ using a FTIR spectroscopy (Thermo Scientific, Nicolet iS10). The morphology and particle size of samples were characterized using Field Emission Scanning Electron Microscope (FESEM) (Hitachi SU8020), where the samples were prepared by deposited on aluminium stubs, dried at room temperature and coated with a layer of platinum using JEOL/JFC-1600 Auto Fine Coater. TEM images were obtained on a Transmission Electron Microscope (TEM) (JEOL 1230). Ag NPs were dropped coated onto a formvar-coated copper grid and dried in a desiccator at room temperature.

\section{SYNTHESIS OF SILVER NANOPARTICLES (Ag NPs)}

Ag NPs were prepared based on a previously reported method (Pillai \& Kamat et al. 2004). Briefly, $125 \mathrm{~mL}$ of
$1 \mathrm{mM} \mathrm{AgNO}{ }_{3}$ was heated to reflux. Subsequently, 1.25 $\mathrm{mL}$ of $1 \% \mathrm{w} / \mathrm{v} \mathrm{Na} \mathrm{C}_{6} \mathrm{H}_{5} \mathrm{O}_{7}$ solution was added dropwise to the boiling $\mathrm{AgNO}_{3}$ solution. Formation of $\mathrm{Ag}$ NPS was indicated by a brownish yellow color change of the solution. Heating was continued for an additional $20 \mathrm{~min}$ and the resulting solution was cooled to room temperature before further use.

\section{DEPOSITION OF Ag NPs ONTO THE GLASS SLIDES}

Briefly, glass slides were first cleaned by immersing them into a piranha solution ( $3: 1$ mixture of $\mathrm{H}_{2} \mathrm{SO}_{4}$ and $\mathrm{H}_{2} \mathrm{O}_{2}$ ) for $1 \mathrm{~h}$, rinsed with copious amounts of ultrapure water and air-dried. The cleaned glass slides were immersed in $10 \% \mathrm{v} / \mathrm{v}$ APTES in absolute ethanol for $2 \mathrm{~h}$ for amine group functionalization via the silanization process. Thereafter, the glass slides were rinsed with absolute ethanol to remove excess APTES on their surfaces, followed by heat treatment at $120^{\circ} \mathrm{C}$ for $30 \mathrm{~min}$. The silanized glass slides were then immersed in Ag NPs suspension for overnight to allow deposition of Ag NPs onto surfaces of glass slides. Ag NPs-deposited glass slides were rinsed with ultrapure water and dried at room temperature (Agnihotri et al. 2013).

\section{FABRICATION OF Ag NPs-BASED SENSING PROBES}

The fabrication process for Ag NPs-based sensing probes is depicted in Figure 1. Briefly, $55 \mu \mathrm{g} / \mathrm{mL}$ of JEV antibodies was dropped onto the Ag NPs-deposited glass slides, incubated for $2 \mathrm{~h}$ at $37^{\circ} \mathrm{C}$ and followed by thoroughly rinsing with PBS to remove unattached JEV antibodies. $1 \%$ w/v BSA was then added to block the unsaturated and nonspecific binding sites on the surfaces of Ag NPs, washed with PBS and air-dried. For the detection of JEV antigen, $200 \mu \mathrm{L}$ solution of JEV antigen was dropped directly onto the Ag NPs-based sensing probe, incubated for $1 \mathrm{~h}$ at $37^{\circ} \mathrm{C}$, rinsed and dried at room temperature.

\section{RESULTS AND DISCUSSION}

\section{SYNTHESIS AND CHARACTERIZATION OF SILVER NANOPARTICLES (Ag NPs)}

Ag NPs were synthesized via the Turkevich method (Pillai \& Kamat 2004) by chemical reduction using $\mathrm{Na}_{3} \mathrm{C}_{6} \mathrm{H}_{5} \mathrm{O}_{7}$ as the reducing agent. The chemical equation is as shown in (1) (Rashid et al. 2013).

$$
\begin{aligned}
& 4 \mathrm{Ag}^{+}+\mathrm{Na}_{3} \mathrm{C}_{6} \mathrm{H}_{5} \mathrm{O}_{7}+2 \mathrm{H}_{2} \mathrm{O} \rightarrow 4 \mathrm{Ag}+ \\
& \mathrm{C}_{6} \mathrm{H}_{5} \mathrm{O}_{7} \mathrm{H}_{3}+3 \mathrm{Na}^{+}+\mathrm{H}^{+}+\mathrm{O}_{2}
\end{aligned}
$$

UV-Vis absorption spectrum showed a sharp surface plasmon resonance peak at a wavelength of around $415 \mathrm{~nm}$ (Figure 2(a)), confirming the formation of Ag NPs (Rashid et al. 2013). As observed in the TEM micrograph (Figure 2(b)), Ag NPs synthesized were spherical in shape with mean particle size of $51.2 \pm 4.3 \mathrm{~nm}$ in diameter. 


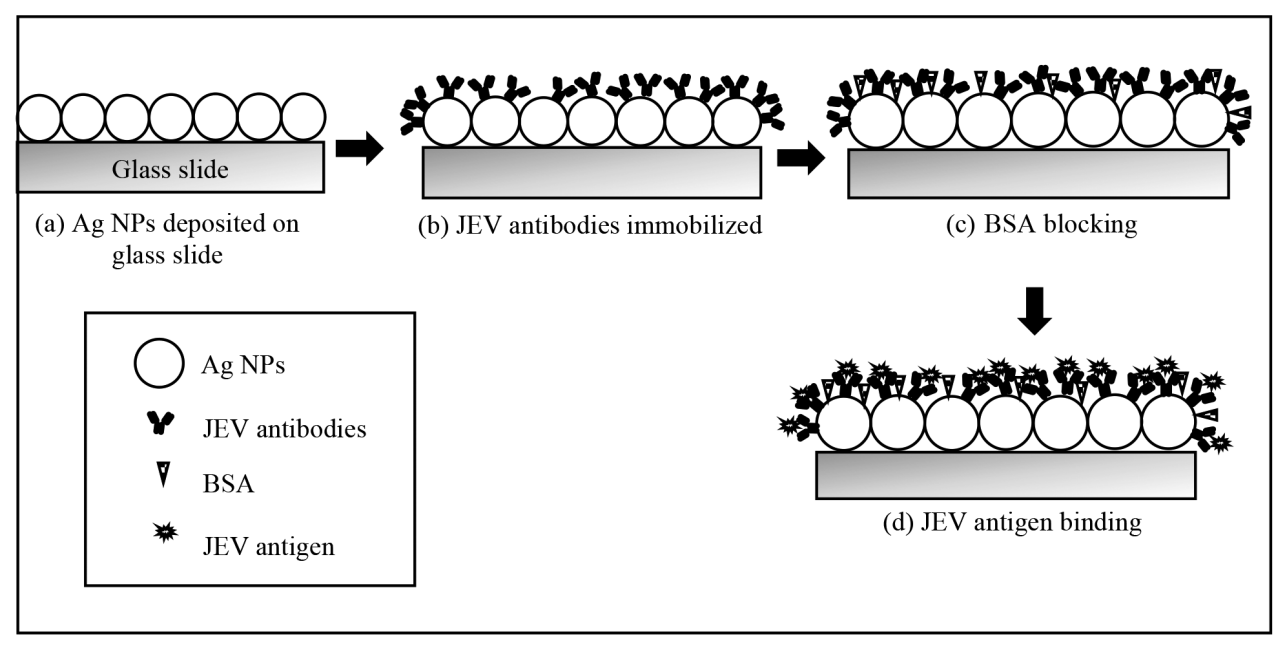

FIGURE 1. Schematic representation of the fabrication process for Ag NPs-based sensing probe (a) Ag NPs deposited on glass slide, (b) JEV antibodies immobilized, (c) BSA blocking and (d) JEV antigen binding

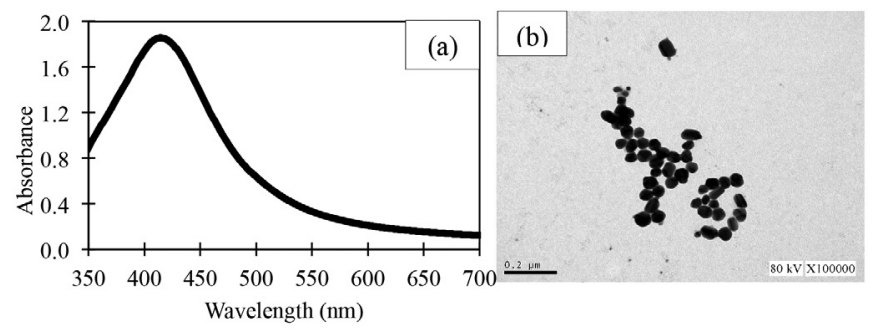

FIGURE 2. Characterization of Ag NPs (a) UV-Vis absorbance spectrum and

(b) Transmission Electron Microscope micrograph

\section{DEPOSITION OF Ag NPs ONTO THE GLASS SLIDES}

Figure 3 shows the schematic representation of the preparation of Ag NPs-deposited glass slides. Agnihotri et al. (2013) suggested that acid hydrolysis (Figure 3a) could generate uniform silanol groups $(\mathrm{Si}-\mathrm{OH})$ on the glass slides. Subsequently poly-condensation of APTES (Figure 3(b)) took place for the formation of siloxane ( $\mathrm{Si}-\mathrm{O}-\mathrm{Si})$ bonds within the silanol sites on the glass surfaces and

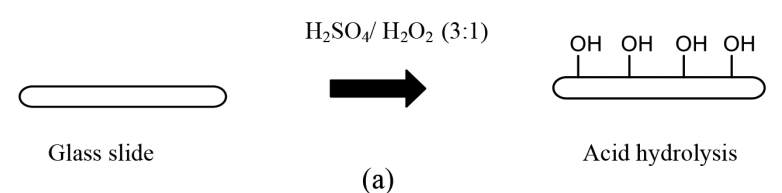

(a)

(b) $\downarrow \begin{aligned} & 10 \% \text { APTES } \\ & 120^{\circ} \mathrm{C}\end{aligned}$

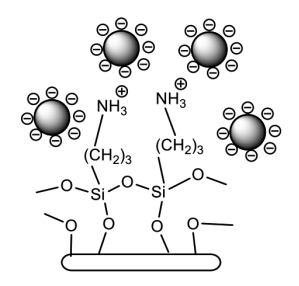

Ag NPs-deposited glass slide

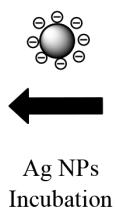

(c)

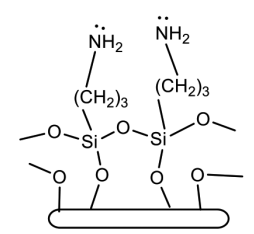

Silanized glass surface

FIGURE 3. Schematic representation of the preparation of Ag NPs-deposited glass slide (a) acid hydrolysis of glass slide to generate silanol group $(\mathrm{Si}-\mathrm{OH})$, (b) formation of siloxane ( $\mathrm{Si}-\mathrm{O}-\mathrm{Si}$ ) by APTES via condensation reaction and (c) immobilization of Ag NPs onto the surface of glass slide 
between aminosilane molecules during the heat treatment (Sharma et al. 2012). When silanized glass slides were immersed into Ag NPs suspension, the color of glass slides turned from colorless to yellow tinted. Ag NPs were deposited onto the surfaces of glass slides (Figure 3(c)) as positively charged ammonium ions of APTES would attract negatively charged citrate stabilized Ag NPs onto the surfaces of glass slides via electrostatic forces (Agnihotri et al. 2013; Rashid et al. 2013). Figure 4 shows the FESEM micrographs of Ag NPs-deposited glass slides. Ag NPs were observed to be well-dispersed and deposited uniformly on the glass slides.

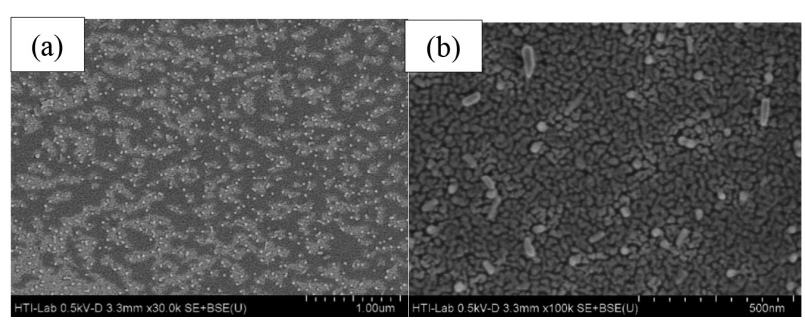

FIGURE 4. FESEM images of Ag NPs-deposited glass slides at different magnifications (a) $30,000 \times$ and (b) $100,000 \times$

\section{CHARACTERIZATION OF Ag NPs-BASED SENSING PROBES}

Figure 5 depicts FTIR spectra of Ag NPs (Figure 5(a)) and Ag NPs with JEV antibody immobilized (Figure $5(b))$, respectively. The absorption peak at $1641 \mathrm{~cm}^{-1}$ was attributed to the amide $\mathrm{I}$ band of $\mathrm{C}=\mathrm{O}$ stretching frequency (Baldassarre et al. 2015), whereas the absorption peak around $1526 \mathrm{~cm}^{-1}$ indicated amide II band with $\mathrm{N}-\mathrm{H}$ bending from JEV antibody (Tran et al. 2011). This suggested that JEV antibody was successfully immobilized onto the surfaces of Ag NPs. The absorbance peak at 1383 $\mathrm{cm}^{-1}$ was the characteristic absorption of $\mathrm{RCO}_{2}$ symmetric and asymmetric stretching of $\mathrm{Na}_{3} \mathrm{C}_{6} \mathrm{H}_{5} \mathrm{O}_{7}$ which was used to synthesize Ag NPs (Tran et al. 2011).

Figure 6 represents UV-Vis absorption spectra of Ag NPs-based sensing probes under different experimental conditions. Ag NPs-deposited glass slides exhibited strong surface plasmon resonance absorption at $420 \mathrm{~nm}$ (Figure 6(a)). The absorption peak of the Ag NPs deposited on the sensing probe was observed to have shifted toward a longer wavelength $(420 \mathrm{~nm})$ and broaden as compared to that of free Ag NPs $(415 \mathrm{~nm})$. This might be due to the difference in the distribution of inter-particle distances, as well as sizes of free Ag NPs and Ag NPs deposited

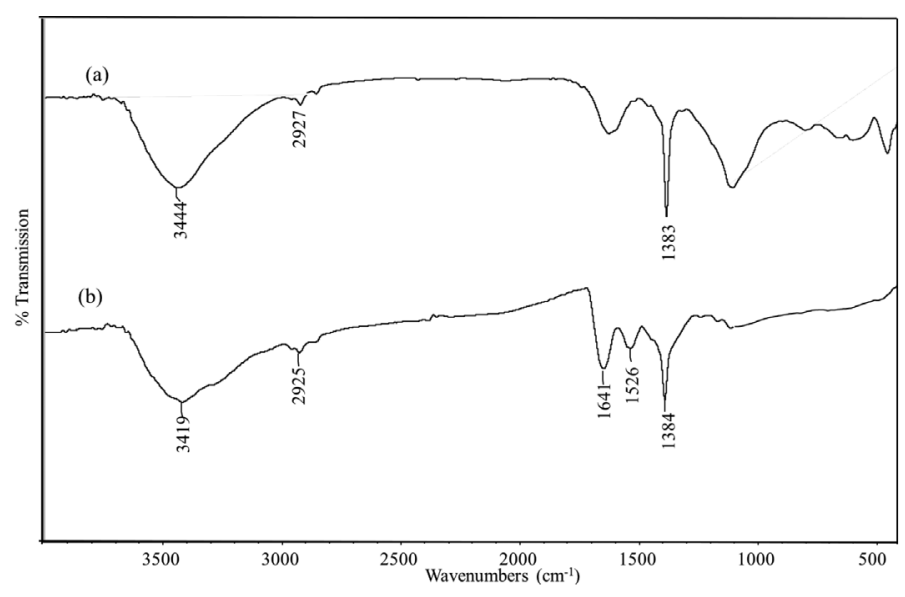

FIGURE 5. FTIR spectra of (a) Ag NPs and (b) JEV antibody immobilized onto Ag NPs

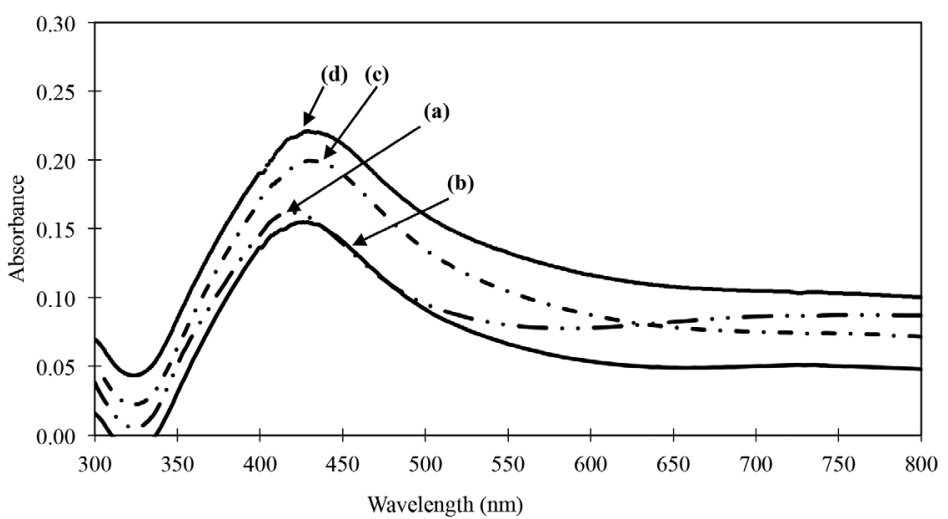

FIGURE 6. UV-Vis absorbance spectra of Ag NPs-based sensing probes (a) Ag NPs only,

(b) JEV antibody immobilized, (c) BSA blocking and (d) JEV antigen binding 
on the sensing probes (Endo et al. 2005). Upon surface functionalization of Ag NPs with JEV antibody (Figure $6 \mathrm{~b})$ and addition of BSA to block any non-specific binding sites (Figure 6c), the wavelength of surface plasmon resonance absorptions were observed to have red-shifted to $427 \mathrm{~nm}$ as compared to that of non-functionalized $\mathrm{Ag}$ NPS-deposited glass slide. The shifting of wavelength could be due to the change of index of refraction around the Ag NPs induced by both JEV antibodies and BSA (Sharma et al. 2012), which also indicated successful immobilization of JEV antibody onto the Ag NPs-based sensing probe (El-Sayed et al. 2005). The binding of JEV antigen onto antibody immobilized Ag NPs-based sensing probes had further enhanced the intensity of surface plasmon resonance absorption at the wavelength of 427 nm (Figure 6d) (Frederix et al. 2003).

\section{OPTIMIZATION OF EXPERIMENTAL CONDITIONS}

Figure 7 depicts parameters for the optimization of the performance of Ag NPs sensing probes, there are concentration of JEV antibody, incubation time of BSA and analysis time of JEV antigen. From Figure 7(a), no distinct absorbance at $427 \mathrm{~nm}$ changes observed for JEV antibody concentration higher than $50 \mu \mathrm{g} / \mathrm{mL}$. As for the effect of incubation time of BSA, the absorbance was observed to increase until $120 \mathrm{~min}$ and reached a plateau (Figure 7(b)). Subsequently, for the analysis assay time of JEV antigen, $1 \mu \mathrm{g} / \mathrm{mL}$ of JEV antigen was used. As shown in Figure 7(c), the absorbance at $427 \mathrm{~nm}$ increased with time in the first 60 min and no significant changes were observed since. This showed that the surface reached saturation and longer incubation time is not needed. At the same time, no significant changes in absorbance proven there is no leaching of immobilized Ag NPs on glass surface.

\section{DETECTION OF JEV ANTIGEN}

Upon binding of JEV antigen on BSA immobilized Ag NPS biosensing probes, further change of surface plasmon resonance absorption of Ag NPs were observed to occur. Such change would lead to a corresponding increase in the absorbance intensity at $427 \mathrm{~nm}$ (Figure 8(a)) (Huy et al. 2011). Similar optical absorption characteristics had been reported for the detection of fibrinogen using gold nanoparticles (Hrapovic et al. 2003). Figure 8(b) shows the linear correlation between the absorbance (A) of $\mathrm{Ag}$ NPs-based sensing probes and the logarithm concentration of JEV antigen within the range of 14 to $100 \mathrm{ng} / \mathrm{mL}$ as shown in (2).

$$
\mathrm{A}=0.0218 \log _{10}\left[\mathrm{C}_{\mathrm{JEV}}\right]+0.1846
$$

where $\left[\mathrm{C}_{\mathrm{JEV}}\right]$ is the concentration of JEV.

The values of regression coefficient $\left(\mathrm{R}^{2}\right)$ and standard deviation $(\sigma)$ were 0.9871 and 0.008045 , respectively. The detection sensitivity (s) of the biosensor is defined as the minimum change in the absorbance per unit concentration of JEV antigen (Sharma et al. 2010). The detection sensitivity (s) of Ag NPs-based sensing probe determined
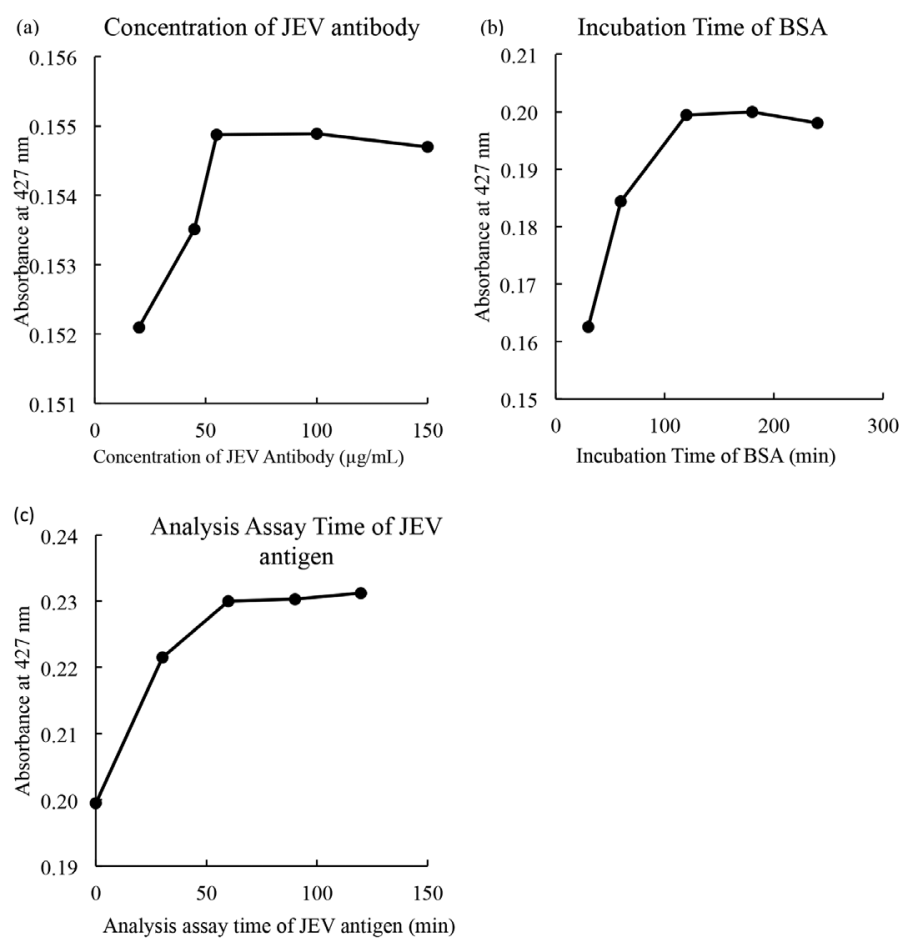

FIGURE 7. Effect of various experimental conditions on absorbance of Ag NPs-based sensing probes at $427 \mathrm{~nm}$ : (a) Concentration of JEV antibody, (b) incubation time of BSA, and

(c) analysis assay time of JEV antigen 

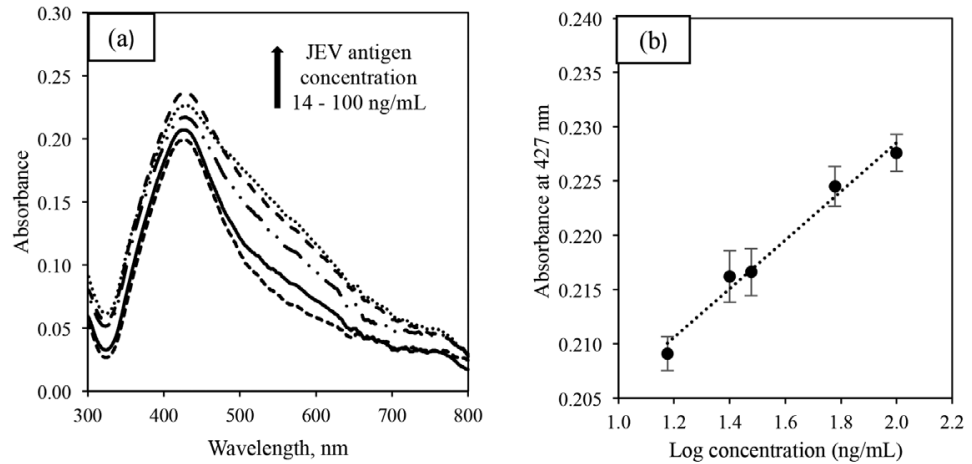

FIGURE 8. Effect of JEV antigen concentrations on the responses of Ag NPs-based sensing probes (a) UV-Vis spectra within the wavelength range of $300-800 \mathrm{~nm}$ and (b) absorbance value at $427 \mathrm{~nm}$
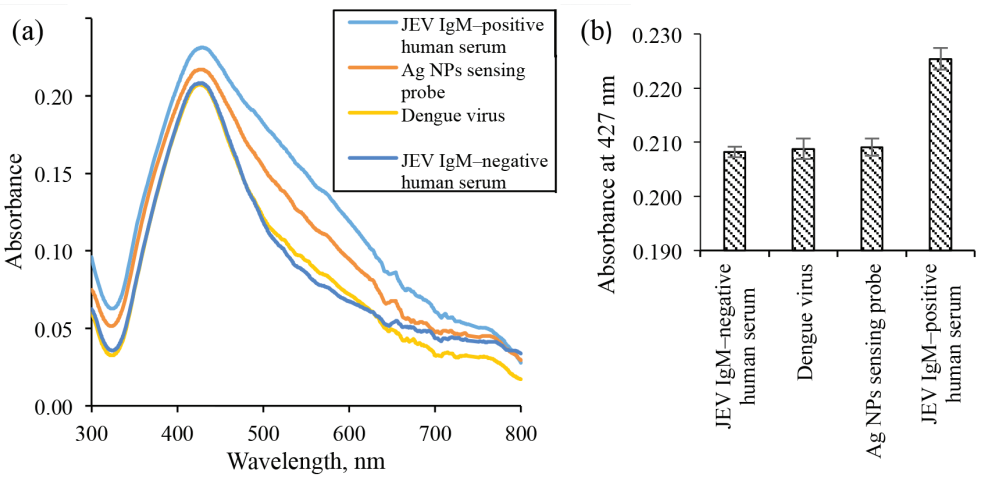

FIGURE 9. Effect of various samples on the responses of Ag NPs-based sensing probes (a) UV-Vis spectra within the wavelength range of $300-800 \mathrm{~nm}$ and (b) absorbance value at $427 \mathrm{~nm}$

from the slope of (2) was $0.0218 \mathrm{~mL} / \mathrm{ng}$. The limit of detection (LOD) of Ag NPs-based sensing probes defined as $3 \mathrm{\sigma} / \mathrm{s}$, was calculated to be $12.8 \mathrm{ng} / \mathrm{mL}$. The LOD value for JEV antigen detection reported here is comparable and within the range of 0.75 to $10 \mathrm{ng} / \mathrm{mL}$ for reported electrochemical biosensors (Huy et al. 2011; Li et al. 2011; Tran et al. 2012). Nevertheless, the novel Ag NPs-based sensing probe reported herein is fabricated using a comparatively simple fabrication process involving a facile silanization step for depositing Ag NPs onto glass/mica slides without the need of any sophisticated instruments such as chemical vacuum depositor and requires fewer immobilization steps. Compared to existing optical biosensors, the Ag NPs-based sensing probe reported here is offers a more rapid detection time of approximately $1 \mathrm{~h}$, is cheaper and easier to operate for point of care JEV antigen detection. Apart from that, the sensing probe was observed to be stable when it was stored in freezer at $4^{\circ} \mathrm{C}$ under dry atmosphere for a period of at least 6 months.

To investigate the selectivity of Ag NPs sensing probe for JEV detection, real clinical sample of JEV IgM-positive human serum, JEV IgM-negative human serum sample and dengue virus were evaluated under the same condition as for JEV antigen. Figure 9 shows that in the presence of human serum as interferences, Ag NPs sensing probe did not show any observable changes in absorbance intensity as compared to that of JEV antigen. When JEV IgM-positive human serum was used, Ag NPs sensing probes showed an absorbance of 0.2254 , within the detection range of $14-100 \mathrm{ng} / \mathrm{mL}$ (Figure 9(a)). Furthermore, the selectivity of Ag NPs sensing probes were verified as there was no observable change in absorbance intensity was seen when dengue virus was used as analytes.

\section{CONCLUSION}

We have reported herein a novel Ag NPs-based optical sensing probe for the detection of JEV. Ag NPs-based sensing probes were fabricated by immobilizing JEV antibodies onto surfaces of Ag NPs which were attached onto amine functionalized glass slides. The presence of JEV was detected by measuring changes in the surface plasmon absorbance at $466 \mathrm{~nm}$. The Ag NPs-based sensing probe showed a detectable JEV concentration range between 14 to $100 \mathrm{ng} / \mathrm{mL}$, with a LOD of $12.8 \mathrm{ng} / \mathrm{mL}$ and an analysis assay time of $1 \mathrm{~h}$. The Ag NPs-based optical sensing probe reported herein is of comparable LOD but more users friendly, rapid and cost effective than those of existing optical biosensors. The potential utility of this novel Ag NPs-based optical sensing probe as an alternative to conventional biosensing techniques for accurate detection of JEV antigen is therefore envisaged. 


\section{ACKNOWLEDGEMENTS}

Financial support from the Ministry of Higher Education (MOHE), Malaysia through Fundamental Research Grant Scheme (FRGS), Grant no. FRGS/STG05(01)/960/2013(01) and MyBrain15 (MyMaster) Programme as well as Universiti Malaysia Sarawak Zamalah for graduate scholarship were gratefully acknowledged.

\section{REFERENCES}

Agnihotri, S., Mukherji, S. \& Mukherji, S. 2013. Immobilized silver nanoparticles enhance contact killing and show highest efficacy: Elucidation of the mechanism of bactericidal action of silver. Nanoscale 5: 7328-7340.

Baldassarre, M., Li, C., Eremina, N., Goormaghtigh, E. \& Barth, A. 2015. Simultaneous fitting of absorption spectra and their second derivatives for an improved analysis of protein infrared spectra. Molecules 20: 12599-12622.

Campbell, G.L., Hills, S.L., Fischer, M., Jacobson, J.A., Hoke, C.H., Hombach, J.M., Marfin, A.A., Solomon, T., Tsai, T.F., Tsu, V.D. \& Ginsburg, A.S. 2011. Estimated global incidence of Japanese encephalitis: A systematic review. BMC Medicine 89: 766-774.

Cardosa, M.J., Wang, S.M., Sum, M.S.H. \& Tio, P.H. 2002. Antibodies against prM protein distinguish between previous infection with dengue and Japanese encephalitis viruses. $B M C$ Microbiology 2: 9.

Chen, Z., Liao, Y., Ke, X., Zhou, J., Chen, Y., Gao, L., Chen Q. \& Yu, S. 2011. Comparison of reverse transcription loop-mediated isothermal amplification, conventional PCR and real-time PCR assays for Japanese encephalitis virus. Molecular Biology Reports 38: 4063-4070.

Chin, S.F., Iyer, K.S. \& Raston, C.L. 2009. Facile and green approach to fabricate gold and silver coated superparamagnetic nanoparticles. Crystal Growth and Design 9: 2685-2689.

El-Sayed, I.H., Huang, X. \& El-Sayed, M.A. 2005. Surface plasmon resonance scattering and absorption of anti-EGFR antibody conjugated gold nanoparticles in cancer diagnostics: Applications in oral cancer. Nano Letters 5: 829-834.

Endo, T., Yamamura, S., Nagatani, N., Morita, Y., Takamura, Y. \& Tamiya, E. 2005. Localized surface plasmon resonance based optical biosensor using surface modified nanoparticle layer for label-free monitoring of antigen-antibody reaction. Advance Material 6(5): 491-500.

Frederix, F., Friedt, J., Choi, K., Laureyn, W., Campitelli, A., Mondelaers, D., Maes, G. \& Borghs, G. 2003. Biosensing based on light absorption of nanoscaled gold and silver particles. Analytical Chemistry 7: 6894-6900.

Hrapovic, S., Liu, Y., Enright, G., Bensebba, F. \& Luong, J.H.T. 2003. New strategy for preparing thin gold films on modified glass surfaces by electrodeless deposition. Langmuir 19: 3958-3965.

Huy, T.Q., Hanh, N.T.H., Thuy, N.T., Chung, P.V., Nga, P.T. \& Tuan, M.A. 2011. A novel biosensor based on serum antibody immobilization for rapid detection of viral antigens. Talanta 86: 271-277.

Jensen, T.R., Malinsky, M.D., Haynes, C.L. \& Duyne, R.P.V. 2000. Nanosphere lithography: Tunable localized surface plasmon resonance spectra of silver nanoparticles. Journal of Physical Chemistry: B 104: 10549-10556.

Kumar, A., Kumar, R. \& Kaur, J. 2012. Japanese Encephalitis: Medical emergency in India. Asian Journal of Pharmaceutical and Clinical Research 5: 9-12.
Labib, M., Martić, S., Shipman, P.O. \& Kraatz, H. 2011. Electrochemical analysis of HIV-1 reverse transcriptase serum level: Exploiting protein binding to a functionalized nanostructured surface. Talanta 85: 770-778.

Lee, H.J., Min, K.I., Park, K.H., Choi, H.J., Kim, M.K., Ahn, C.Y., Hong, Y.J. \& Kim, Y.B. 2014. Comparison of JEV neutralization assay using pseudotyped JEV with the conventional plaque-reduction neutralization test. Journal of Microbiology 52: 435-440.

Li, F., Mei, L., Li, Y., Zhao, K., Chen, H., Wu, P., Hua, Y. \& Cao, S. 2011. Facile fabrication of magnetic gold electrode for magnetic beads-based electrochemical immunoassay: Application to the diagnosis of Japanese encephalitis virus. Biosensors and Bioelectronic 26: 4253-4256.

Oya, A. \& Kurane, I. 2007. Japanese Encephalitis for a reference to international travelers. Journal of Travel Medicine 14: 259-268.

Pillai, Z.S. \& Kamat, P.V. 2004. What factors control the size and shape of silver nanoparticles in the citrate ion reduction method? Journal of Physical Chemistry: B 108: 945-951.

Rashid, M.U., Bhuiyan, M.K.H. \& Quayum, M.E. 2013. Synthesis of silver nano particles (Ag-NPs) and their uses for quantitative analysis of vitamin C tablets. Journal of Pharmaceutical Sciences 12: 29-33.

Riboh, J.C., Haes, A.J., McFarland, A.D., Yonzon, C.R. \& Duyne, R.P.V. 2003. A nanoscale optical biosensor: Real-time immunoassay in physiological buffer enabled by improved nanoparticle adhesion. The Journal of Physical Chemistry 107: 1772-1780.

Sharma, A., Matharu, Z., Sumana, G., Solanki, P.R., Kim, C.G. \& Malhotra, B.D. 2010. Antibody immobilized cysteamine functionalized-gold nanoparticles for aflatoxin detection. Thin Solid Films 519: 1213-1218.

Sharma, P., Kumar, B. \& Suri, C.R. 2012. Antibody functionalized gold nanoprobes based colorimetric assay for the direct detection of phenylurea herbicide. Environment and Pollution 1: 12-19.

Sirivichayakul, C., Sabchareon, A., Limkittikul, K. \& Yoksan, S. 2014. Plaque reduction neutralization antibody test does not accurately predict protection against dengue infection in Ratchaburi cohort, Thailand. Virology Journal 11: 48.

Solomon, T. 1997. Viral encephalitis in Southeast Asia. Neurological Infections and Epidemiology 2: 191-199.

Solomon, T., Kneen, R., Dung, N.M., Khanh, V.C. \& Thuy, T.T. 1998. Poliomyelitis-like illness due to Japanese encephalitis virus. Lancet 351: 1094-1097.

Swami, R., Ratho, R.K., Mishra, B. \& Singh, M.P. 2008. Usefulness of RT-PCR for the diagnosis of Japanese encephalitis in clinical samples. Scandinavian Journal of Infectious Diseases 40: 815-820.

Szymanski, M.S. \& Porter, R.A. 2013. Preparation and quality control of silver nanoparticle-antibody conjugate for use in electrochemical immunoassays. Journal of Immunological Methods 387: 262-269.

Tam, P.D., Tuan, M.A., Huy, T.Q., Le, A. \& Hieu, N.V. 2010. Facile preparation of a DNA sensor for rapid herpes virus detection. Materials Science and Engineering: C 30: 11451150.

Tran, Q.H., Hanh, N.T.H., Chung, P.V., Anh, D.D., Nga, P.T. \& Tuan, M.A. 2011. Characterization of immobilization methods of antiviral antibodies in serum for electrochemical biosensors. Applied Surface Science 257: 7090-7095. 
Tran, Q.H., Nguyen, T.H.H., Mai, A.T., Nguyen, T.T., Vu, Q.K. \& Phan, T.N. 2012. Development of electrochemical immunosensors based on different serum antibody immobilization methods for detection of Japanese encephalitis virus. Advances in Natural Science Nanoscience and Nanotechnology 3: 1-6.

Zhao, J., Zhang, X., Yonzon, C.R., Haes, A.J. \& Duyne, R.P.V. 2006. Localized surface plasmon resonance biosensors. Nanomedicine 1: 219-228.

Department of Chemistry

Faculty of Resource Science and Technology

Universiti Malaysia Sarawak

94300 Kota Samarahan, Sarawak Bumi Kenyalang

Malaysia
*Corresponding author; email: sukfunchin@gmail.com

Received: 1 September 2016

Accepted: 3 April 2017 